Maarit Cederberg, Tuula Hurskainen,

Elisa Mörsky, Sirpa Janhonen, Eija Kajava,

Juha Leppämäki ja Annamari Leppäniemi

\title{
Tietoa vahvistamassa ja saatavuutta parantamassa - NordILL 2021 -konferenssin satoa
}

The 14th Nordic Resource Sharing, Reference and Collection Management Conference (25.-26.10.2021) tarjosi innostavien puhujien lisäksi laajan katsauksen pohjoismaisten kirjastojen innovaatioihin sekä koronapandemian aiheuttamiin muutostarpeisiin kirjastojen palveluissa. Artikkeli luo katsauksen konferenssin teemoihin: aineistojen digitointiin, e-lainaamiseen yli kirjasto- ja maarajojen, asiakastoimisuuden parantamiseen, avoimeen tieteeseen sekä kulttuuriperintöportaaleihin.

$\mathrm{P}$ erinteiset pohjoismaiset kaukopalvelupäivät järjestettiin lokakuun lopulla koronapandemian takia vuosi alkuperäistä suunnitelmaa myöhemmin ja aivan uudella konseptilla: virtuaalisena. NordILL 202 I -konferenssin järjestelyistä päävastuun kantoivat Kansalliskirjasto ja Varastokirjasto, mukana järjestelyissä olivat myös Helsingin yliopisto, Helsingin kaupunginkirjasto ja Helsingin kaupunki. Konferenssissa kuultiin esitykset Pohjoismaiden lisäksi myös Virosta, Latviasta ja Venäjältä.

\section{Koska tietoa täytyy jakaa!}

Konferenssin aloituspäivän pääpuhujiksi oli kutsuttu sekä IFLA-organisaation tuore presidentti Barbara Lison Saksasta että Ifla:n Document Delivery and Resource Sharing -komitean puheenjohtaja Peter Collins, joka toimii OCLC:n Resource Sharing -johtajana USA:ssa. Toisen konferenssipäivän teemojen tunnelmaan viritti Norjan 
kansalliskirjaston johtaja Aslak Sira Myhre.

Barbara Lison kertoi avauksessaan Euroopan aineistonvälityksen tulevaisuuden trendeistä avaamalla IFLA:n strategisen johtamisen teemoja. IFLA:n tavoitteena on mahdollistaa e-aineistojen kaukolainaaminen ja tarjota kaikille pääsy sähköisiin resursseihin. Lisäksi parhaillaan ollaan muuttamassa kansainvälisen kaukopalvelun maksuvälinettä IFLA-vuocheria sähköiseksi.

Peter Collins korosti IFLA:n roolia sähköisen aineiston lainaamisen organisoinnissa. Collins muistutti, että monia kansainvälisen ta-
Kirjastojen täytyy

herätä keskustelemaan

tulevaisuuden

tiedonhakutavoista ja -välineistä. son juridisia kysymyksiä ja aineiston saatavuuden rajoitteita on edelleen ratkaisematta. Hän nosti keskusteluun painetun aineiston tulevaisuuden ja eri formaateissa tarjottavan aineiston tarpeen kirjastoissa. Sekä yleisten että tieteellisten kirjastojen kaukolainatilastot laskivat dramaattisesti vuonna 2020 pandemian vaikutuksesta sysäten liikkeelle digitointiprojekteja.

Aslak Sira Myhre näki tärkeänä digitointityön. Myhre korosti, että kirjastojen täytyy herätä keskustelemaan tulevaisuuden tiedonhakutavoista ja -välineistä. Digitoituna vanha kulttuuriperintö herää uudelleen henkiin. Tämä edellyttää kirjastoilta pääsyn luomista ja ohjaamista eri formaateissa olevaan aineistoon. Asian ytimessä ovat

kirjastoammattilaisten asiantuntemus ja luetteloinnin hallinta.

\section{E-kirjojen lainaus Pohjoismaissa}

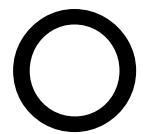
man esityksensä konferenssissa saivat yleisissä kirjastoissa käynnissä olevat kansalliset e-kirjastoprojektit, joita esiteltiin Suomesta, Tanskasta ja Norjasta. Kansallisten projektien keskeinen tavoite on, että e-aineistoihin pääsy ja valikoima ei riippuisi asuinpaikasta. Tavoite on, että rinnakkaiset sähköiset aineistopalvelut saataisiin yhdelle alustalle.

Eri maiden e-kirjastoprojektit ovat hyvin eri vaiheissa. Mikkel Christoffersen esitteli Tanskan eReolen, joka on kymmenen vuotta käytössä ollut yleisten kirjastojen yhteinen e-kirjojen ja e-äänikirjojen portaali. Trygve Kikut puhui Norjan projektista, jossa alustan luominen on vasta suunnitteluvaiheessa; Virva Nousiainen-Hiiri ja Suvi Sivulainen kertoivat Suomen Digimedia-hankkeesta, jonka pilotointi on tarkoitus aloittaa vuonna 2022. Esitellyissä e-kirjaprojekteissa vaiheineen ja haasteineen voi havaita paljon samankaltaisuutta.

Kaikille maille yhteinen pohdinnan aihe on palvelun rahoitusmallin luominen kirjastojen ja niitä rahoittavien kuntien kesken. On myös olennaista rakentaa luottamusta kirjastojen ja erilaisten muiden toimijoiden, kuten kustantajien, jakelijoiden ja tekijöiden välille. Kirjaston tulisi passiivisen ostajan sijasta ottaa rooli aktiivisena toi- 
minnan kehittäjänä ja sopijana niin, että kaikki osapuolet hyötyisivät mukana olosta palvelussa.

Tanskassa kirjastot ovat onnistuneet luomaan hyvää yhteistyötä kustantajien kanssa. Kirjaston palvelu on todettu erityisen hyväksi sekä vanhemman kirjallisuuden että lasten- ja nuortenkirjallisuuden esiin nostamiseen. Isojen kustantajien uusia nimekkeitä on esillä erityisesti siksi, että ne houkuttelevat uusia käyttäjiä palveluun, vaikka varausjonot kasvavat välillä pitkiksi.

Koronasulkujen aikana Tanskan eReolenin käyttö lisääntyi ja palvelusta tuli niin suosittu, että sen toimintamallia joudutaan kehittämään korkeiden kustannusten vuoksi. Sopivan palvelutason määrittäminen on haasteellista, mutta tavoitteena on edelleen kiinnostavan palvelun tarjoaminen asiakkaille.

\section{Uusia kehityssuuntia kaukopalvelussa ja aineistojen yhteiskäytössä}

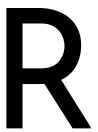

iin Olonen Viron kansalliskirjastosta esitteli uutta valtakunnallista lainausjärjestelmää Books on the Move, joka otetaan käyttöön ensi vuoden aikana. Sen sijaan, että kirjastoa pyydetään tilaamaan kirjat toisesta kirjastosta, tarjotaan asiakkaille mahdollisuus tilata kirjoja verkossa ja noutaa ne haluamastaan kirjastosta. Järjestelmä ohjaa pyynnön oikeaan kirjastoon. Palvelua kehitetään edelleen, sillä Virossa on 800 kirjastoa ja erilaisia kirjastojärjestelmiä käytössä. Lisäksi Virossa on kehitteillä Ystävältä ystävälle -palvelu, jossa kirjalaina voidaan siirtää lainaajan tililtä toiselle ja samalla vastuu siirtyy uudelle lainaajalle. Molempien lainaajien täytyy olla rekisteröityneitä käyttäjiä eikä kirjaan saa olla varauksia.

Lovisa Karlsson Kjellin ja Tobias kertoivat Bläddrasta, joka on e-kirjasovellus mobiililaitteille ja tableteille. Bläddralla on ilmainen pääsy Ruotsin kansallisten vähemmistökielien kirjoihin. Näitä kieliä ovat suomi, jiddish, meänkieli, romani ja saame. Kansalliskirjasto aloitti palvelun vuonna 2019 kahdella vähemmistökielellä, saamella ja romanilla.

Frida Leijon Lundqvist esitteli Tukholman yliopis-

Tanskassa kirjastot ovat onnistuneet luomaan hyvää yhteistyötä kustantajien kanssa. ton asiakaslähtöistä kaukopalvelu-, aineistonhankinta- ja open access -mallia. Kirjastossa on kolme ryhmää: hankinta, kaukopalvelu ja lisenssi/open access -ryhmä, jotka toimivat yhteistyössä. Asiakkaiden hankintapyynnöt otetaan vastaan yhdellä lomakkeella. Sen jälkeen eri tapaukset ohjataan jollekin kolmesta osastosta sen perusteella, mikä niistä on paras hankintatapa kyseiselle aineistolle. Koska kaukopalvelu on painottunut vanhemman aineiston hankintaan, uudemman aineiston open access -kehitys ei ole juurikaan vaikuttanut kaukopalvelutilausten määrään.

Jyväskylän kaupunginkirjaston Shokkiuutinen-hankkeen projekti- 


\section{4}

n
O
C
3
N
O
N

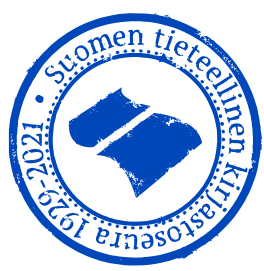

updating

infodemics

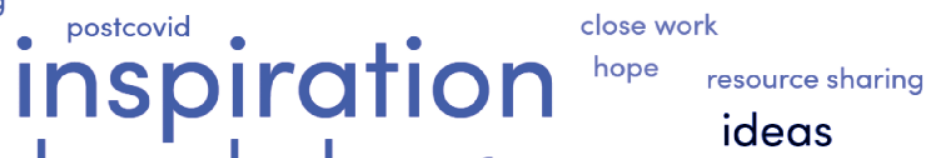

insights knowledge future

tips

\section{new ideas}

collaboration Vision news

e-lending

Konferenssissa tietyt teemat ovat toistuneet vuosien varrella, vaikka uuttakin oppii. Kuva: Jussi Saari

suunnittelija Anne Koivisto kertoi hankkeen kolmesta osahankkeesta: Jyväskylän kaupunginkirjaston varastokokoelman läpikäynti auttaa uuden kirjastotilan vähenevissä kokoelmatiloissa, kun aineistoa siirretään Varastokirjastoon. VATI-projekti parantaa asiakaslähtöisyyttä, Varastokirjaston kokoelmat näkyvät KESKI-Finnaan kirjautuneelle asiakkaalle ja hän voi myös itse tehdä tilauksen Varastokirjaston aineistoon. ATTE-projektissa tehtiin esiselvitys kirjastojärjestelmäriippumattoman kaukopalvelun mahdollisuuksista. Asiakaslähtöisen, järjestelmäriippumattoman ja standardin mukaisen yhteisen kaukopalveluratkaisun etsintää jatketaan Varastokirjaston AIRUT-projektissa.

Elina Kähö ja Juha Leppämäki esittelivät Helsingin yliopiston kirjaston Alma-kehittämishanketta. Kaukopalvelun useammat erilliset järjestelmät korvattiin Alma-kirjastojärjestelmän kaukopalveluominaisuuksilla. Tässä hyödynnetään sekä asiakasliittymä Primon kaukopalvelulomaketta että Alman rajapintoja tilausten vastaanottamiseen asiakkailta ja muilta kirjastoilta. Asiakaslähtöisyys lisääntyi niin, että nyt kaukolainat näkyvät Helkan asiakastiedoissa muiden lainojen ja varausten tapaan.

\section{Avoimet tiedejulkaisut}

Avointen tiedejulkaisujen (Open Access Journals) kansallisia alustoja esiteltiin neljästä maasta. Palvelut tarjoavat erilaisille toimijoille teknisen alustan tieteellisten lehtien julkaisemiseen.

Jesper Boserup Thestrup edusti tanskalaista Tidsskrift.dk -palvelua, joka on ollut käytössä vuodesta 2007. Avoimen julkaisualustan käyttö on pelastanut tieteellisiä julkaisuja lakkauttamiselta, ja alustalla saavat näkyvyyttä myös historialliset tiedejulkaisut.

Suomesta Antti-Jussi Nygård nosti esiin Journal.fi-alustan, jota ylläpitää Tieteellisten seurain valtuuskunta. Tavoitteena ollut edullinen alusta open access -julkaisemiseen toteutui. Alustan julkaisuvuodesta 20 I 7 lähtien tarjolla olevien julkaisujen määrä on kasvanut jatkuvasti.

Jeroen Sondervan Alankomaista esitteli tänä vuonna julkaistun palvelun Openjournals.nl. Julkaisijoille asetetaan palvelussa joitakin vaatimuksia, kuten avointen Creative Commons -lisenssien käyttö. Myös toimitusprosessille asetetaan ehtoja, esimerkiksi vertaisarviointi.

Ruotsin kansalliskirjaston ylläpitämästä Publicera-alustasta kertoi Sofie Wennström. Alustan käyttö on julkaisijoille ilmaista, mutta esimerkiksi julkaisuformaattia rajoitetaan. Publicera 



\section{6}

aikakauslehtisivua. Palvelussa on mukana myös muuta aineistoa, kuten väitöskirjoja, käsikirjoituksia, kirjoja ja pienpainatteita.

Latvian kansalliskirjaston johtaja Arturs Zogla kertoi kirjojen ja lehtien digitoinnista. Kansalliskirjaston kautta on digitaalisessa muodossa saatavilla noin I 3 ooo kirjaa ja I 500 lehtinimekettä. Latviassa koronavirustilanne eskaloitui nopeasti vuoden 2020 maaliskuussa, jolloin NLL (National Library of Latvia) suljettiin kokonaan yleisöltä. Kun samaa aikaa pääsyä useimpiin yleisiin kirjastoihin rajoitettiin, tuli tarve siirtyä painetusta aineistosta digitaaliseen. Tekijänoikeudellisista haasteista huolimatta lehdet avattiin osapuolten yhteisellä sopimuksella ilmaiseen käyttöön.

\section{Yhteenveto}

Kahden vuoden välein järjestettävä pohjoismainen konferenssi on tarpeellinen ja antoisa tapa kokoontua yhteisten asioiden äärelle. Aina oppii uutta, vaikka tuttua ja vanhaakin on mukana. Esimerkiksi tietyt teemat ovat toistuneet vuosien varrella, ja tulevat varmasti toistumaan edelleen, kuten avoin saatavuus ja e-lainaus. Niihin liittyy haasteita, joita yritetään yhdessä ratkoa.

Konferenssissa esiin nousseet yhteiset päämäärät ja toiveikkuus loivat kansainvälistä yhteisöllisyyttä, vaikka kollegojen kohtaaminen, vapaa keskustelu ja yhteiset ruokailuhetket puuttuivat - niitä toki toivomme jatkossa. Paikka, jossa kohdataan kahden vuoden kuluttua on vielä arvoitus, mutta perinteisesti tapaamiset on järjestetty vuorotellen Suomessa, Norjassa, Ruotsissa, Tanskassa ja Islannissa. Yleensä järjestäjävastuu menee järjestyksessä niin, että se jolla on pisin aika konferenssin järjestämisestä on seuraavana vuorossa. Odotamme innolla!

Kiitokset innovatiivisesta ja ajatuksia herättävästä NordILL 202 I -konferenssista erityisesti Varastokirjaston kirjastonjohtaja Johanna Vesteriselle ja Kansalliskirjaston apulaiskirjastonjohtaja Liisa Savolaiselle sekä tapahtuman etenemisestä konferenssin aikana vastanneelle moderaattori Päivi Jokitalolle! Järjestelyt ja yhteydet toimivat erinomaisesti.

\section{Kirjoittajat}

MaArit Cederberg

Tampereen yliopiston kirjasto maarit.cederberg@tuni.fi
Tuula Hurskainen

Suomen ympäristökeskuksen tietopalvelu tuula.hurskainen@syke.fi

$\begin{array}{ccc} & \text { SiRPA JANHONEN } & \\ \text { Elisa MÖRSKY } & \text { Varastokirjasto } & \\ \text { Kansalliskirjasto } & \text { sirpa.janhonen@nrl.fi } & \text { EIJA KAJAVA } \\ \text { elisa.morsky@helsinki.fi } & & \text { Eduskunnan kirjasto } \\ \text { eija.kajava@eduskunta.fi }\end{array}$

JUHA LeppämäKI

Helsingin yliopiston kirjasto

juha.leppamaki@helsinki.fi
ANNAMARI LePpÄNIEMI

Turun yliopiston kirjasto

annamari.leppaniemi@utu.fi 